\title{
High-tech Horticulture: Protected Vegetables Production in Subtropics under Changing Climatic Scenario
}

\author{
K.S. Yadav* \\ Jawahar Lal Nehru Krishi Vishwa Vidyalaya, Krishi Vigyan Kendra Sagar, MP, India \\ *Corresponding author
}

\begin{abstract}
A B S T R A C T
Green house is a polyhouse or plastic house covered with polythene sheet. It is light in

Keywords

Protected cultivation, Parthenocarpic cucumber, Vegetable seedlings, climate change

\section{Article Info}

\section{Accepted:}

08 July 2018

Available Online:

10 August 2018 weight, easy to handle and cheaper in cost, resistant to hail, frost, over heating as well as very suitable for off-season vegetables cultivation. Vegetable growers can substantially increase their income by cultivation of vegetable under protected condition during off season as the vegetables produced during their normal season generally they do not found good returns due to availability of these vegetables in the market. Green house cultivation as well as other modes of controlled environment cultivation has been evolved to create favorable micro climate, which favor's the crop production could be possible throughout the year or part of the year as required. Low cost and naturally ventilated polyhouse is very suitable and most profitable technology for subtropics or is plains of India. Greenhouse is the very effective to raise the off-season nursery, off season vegetable high value crop for long duration i.e. Tomato, Capsicum, Cucumber, Bottlegaurd, early Cauliflower, Coriander, Cabbage etc. Apart from these insect proof net houses provide virus and insect free ideal conditions for production of those vegetable mainly during the rainy season. Various research results have shown that by adopting protected cultivation productivity of vegetable crops can be increased by 3 to 5 times as compared to open environment. This aspect needs to be extensively exploited in India and MP as has been done elsewhere in the
\end{abstract}

\section{Introduction}

Vegetables are important constituents of Indian agriculture and nutritional security due to their high yield, short duration crops, riche sources of vitamins and minerals, economic viability, and employment generation. Environmental, stress is the primary causes of crop losses worldwide, reducing average yield for most major crops by more than $50 \%$. Global climate change especially erratic rain fall pattern and unpredictable high temperature in the plain (Subtropic and tropics) spells will reduce the productivity of vegetable crop.

\section{Causes of climate changes}

Deforestation

Fossil fuel consumption

Urbanization

Land reclamation

Fresh water extraction

Fisheries over exploitation

Waste production (Erickson, 2008). 
Hence, due to climate changes and adverse environmental conditions, offseason vegetable may be grown in polyhouse/ greenhouse as protected cultivation. Low cost and naturally ventilated poly house is very imitable for the plains area.

The Indian scenario has changed tremendously during the last decades because of changing in the life style and food habits the people are becoming more aware to eat healthy foods. Vegetable are more important components of health, food and provide nutritional and healthy security. Hence, it is pertinent to grow more vegetables with good quality and clean and green produce. This can be achieved by employing improved agro techniques of precision farming and green house technologies as protected vegetables cultivation.

The need to protect the crops and to sustain production even under unfavorable climates led to development of protected cultivation. To increase quality of produce of high value cash crops having export potential, the only potential approach is perfection and promotion of greenhouse technology.

The relationship between climate change and agriculture is however a two way one; Climate change in general adversely affected agriculture and agriculture contributes to climate change in several major ways. On a global scale, the potential for food production is projected to increase with increases in local average temperature.

Over a range $1-3{ }^{\circ} \mathrm{C}$ but above this it is projected to decrease (IPCC, 2007), given that warming by the end of the $21^{\text {st }}$ century (20902099) will be worse than expected and that the best estimates projects a rise of 1.8- 4 degree Celsius and likely range of 1.1-6.4 degree Celsius, that the world is likely to see a decline in food production.
India produces 178.17 million tons of the vegetables from an area of 10.23 million hectares out of 295.20 million tones and area of 24.90 million hectares of total horticultural crops of India (DAC; 2016-17). In spite of them, Madhya Pradesh produces total vegetables 18.20 million tones an area of 0.93 million hectares out of 27.03 and 1.90 respectively of total horticultural crops. India is the second largest producer of vegetables in the worlds, after china. Hence, the production of vegetables has increased from 58.5 million tones t0 178 million tones since 1991-92 to 2016-17. Our country produces $14 \%$ of world's vegetables on $15 \%$ of world's area under vegetables. However, Productivity of vegetables in India (17.3t/ha) is less than the world average productivity (18.8t/ha). The share of the Indian in world vegetable market is around $14.1 \%$ only. According to FAO and WHO standard recommendation, per capita of vegetables in India is very low $220 \mathrm{~g} /$ day/ capita against $300 \mathrm{~g} /$ day/capita.

At present, the farmers are challenged with growing abundant, safe and nutritious vegetables food for an increasing global population in the form of changing climate and pest and disease pressure.

\section{Opportunities of vegetable production in greenhouse}

The off-season vegetable production in green house or poly house like Tomato, Capsicum, Cucumber, Rose, Carnation give a special significance because of specific flavour, aroma, freshness, plunged shelf life, high value and more production and good keeping quality. Hence, the scope of off-season vegetable production exist a scope for increasing the vegetable production for domestic and International markets. Further, off-season vegetable production in greenhouse or polyhouse helps to bridge the seasonal gap between demand and supply and 
produces more employment opportunities to marginal and small farmers.

\section{Status and importance of greenhouse cultivation}

The area under greenhouse cultivation reported by the end of $20^{\text {th }}$ century was about 110ha, In India and world over 275,000 hectares. During the last decades this area must have increased by 10 per cent if not more. In Asia and China has the largest area under protected cultivation, $2.5 \mathrm{M}$ ha, under playhouse / greenhouse.

In India, in the present scenario of perpetual demand of vegetables and shrinking land holding drastically, protected cultivation is the best alternative and drudgery less approach for using land and other resource more efficiently (Sirohi and Bahera, 2000) . Greenhouse is the most practical methods of accomplishing the objectives of protected cultivation, Tomato, Capsicum and Cucumber are the most extensively grown vegetable in the plains in Natural Ventilated Polyhouse \& Insect Proof net house which is very cheapest and give higher returns.

The practice of protected cultivation of vegetable crops is also becoming popular in the hilly region of the country, which offers a great scope for use of low cost naturally ventilated playhouse in plain in mild climate. It involves protection of production stages of vegetable mainly from adverse environment conditions such as temperature, hail, scorching sun, heavy rains, frost etc. infect, the need to protect the crop against unfavorable environment conditions led to the development of protected cultivation. This is now becoming important due to climate change. Greenhouse if the most practical methods of achieving the objectives of protected horticulture, where natural environment is modified by using sound engineering principles to achieve optimum plant growth and yield. Research results have shown that by adopting green house cultivation productivity of vegetable crop can be increased by 3-5 times as compared to open environment.

\section{Advantages of greenhouse vegetable cultivation}

In Poly house and greenhouse production can reduce the amount of water and chemical fertilizers used in production of high value vegetables compared to open field conditions. The advantages of vegetables grown in polyhouses are:-

1. Vegetable crops grown under adverse weather conditions round the year.

2. Raising of vegetable nursery a transplants under protection.

3. The vegetables can produce with higher productivity and uniform quantity of produce than open field conditions.

4. Easy to management of insect -pests, diseases and weeds.

5. Off-season production of vegetable to get better return to growers is feasible.

6. Use of protected vegetable cultivation can increase production by more activity per unit of land, water, energy and labour.

7. It makes cultivation of vegetables possible in areas where it is not possible in open condition such as high altitudes desert.

8. Dieses free seed production of costly vegetables becomes easy under Greenhouse/Polyhouse.

9. In the hilly areas, there are generally have small land holding and this technology provides a useful impetus to their farming livelihood by more productivity and more money from less land.

10. It makes vertical cultivation of vegetables possible using technology like hydroponics, aeroponics etc. and use of vertical beds for production. 
11. Multiple cropping on the shame land is possible.

\section{Limitations}

1. Lack of practical knowledge of this technology by farmers.

2. Expensive short life and non availability of cladding materials .

3. Manual or hand pollination in cross pollinated vegetables like cucurbitaceous crops.

4. Development of the need to parthenocarpic hybrids varieties which is very costly and not to be easily available.

5. Lack of appropriate tools and machinery.

6. Structure cost initially looks unfavorable. Farmers with zero risk affordability do not come forward to adopt it.

7. Inadequate support from planners and scientists suitable varieties/ hybrids

\section{Polyhouse / greenhouse structures}

Polyhouse/green house is a framed structure having 750-200 micron (600-800 gangues) UV stabilized transparent or translucent low density polyethylene or other cladding which creates green house effects making microclimate favorable for plant growth and its development. Woods, bamboo, GI pipe, angle iron and aluminum are common materials used for the framework of a polyhouse (Table 1).

Generally life of such films have 4-5 years. Following three types of greenhouse are makes in the plains area or subtropics

\section{Low cost green house}

Low cost green house structure constructed with locally materials. The ultraviolet (UV) film is used as cladding materials. No use of specific control devices for regulating the environmental parameters inside the green house. Simple techniques are however adopted for management of the temperature and humidity, light intensity can be reduced by incorporating shading materials like nets.

The temperature can be reduced during summer by opening of side walls such structure is used as rain shelter as well as to protect from low temperature for vegetable cultivation otherwise inside temperature is increased when all side walls are covered with plastic films

\section{Medium cost greenhouse}

In medium cost green house side walls need to be flexible. Usually fan pad cooling system shed net micro sprinkler system adopted during summer to maintain the temperature rise.

Besides, during winter hot air blower may be used to maintain higher temperature.

\section{High cost greenhouse}

To overcome some difficulties as above in both type of greenhouse this is the complete controlling the environment parameters and fully automatically.

At present, computer based advance technology with full automation for temperature, humidity, irrigation, fertigation control is available which can be utilized for high value and low volume vegetable for local consumption and long distance supply.

\section{Selection of vegetables nursery raising techniques}

The selection of crops is more critical in case of ordinary low cost polyhouse in subtropics, Parthenocarpic Cucumber, Capsicum and 
Tomato gives quite remunerative yield during in low cost or natural ventilated polyhouses, with proper ventilation, cabbage, early varieties of tropical cauliflower and coriander can be successfully grown during summer and rainy season also. Besides, various types of healthy disease free vegetable nursery i.e. Tomato, Brinjal, Chilly, early and mid season Cauliflower may be raise or grown in rainy and winter season. Generally, more than $40-$ $60 \%$ germination percentage and healthy seedlings are to be found in polyhouses reported by various researchers. In other hand and various cucurbitaceous vegetables can be grown one month before normal season in poly bags and in plastic pro trays having 1.5 " cell size in the month of December and January and transplanted in normal field in the mid January to mid February.

Generally, vegetables seedlings raise with ordinary care in open field under normal weather conditions, but crops in the winters \& rainy season, the nursery is exposed to adverse weather which resulted in heavy mortality of the seedlings. For example, the nursery period of early and mid season cauliflower coincides with the period of heavy rainfall. The seedlings exposed to intense heat of sun under heavily saturated soil conditions suffer due to damping off problem. A properly ventilated or cooled poly house may ensure the desired population with less seedlings mortality. Similarly, for spring planting the seeds of tomato, brinjal and chilli are sown during December-January, which due to low temperature stress, take unduly long time to germinate and produce transplantable seedlings. Inside a low cost poly house this time period has been found to be reduced by more than one third, besides increase in the seedlings population also.
The Krishi Vigyan Kendra Sagar was conducted various trials on various locations in the districts as well as KVK during the year of 2014 to 2016 on Tomato, brinjal, chilli, capsicum, cauliflower, cabbage crops etc. On average results shown in table below in various environmental conditions which represented Bundelkhand region.

\section{Off season vegetables cultivation}

We knows that generally Tomato, Capsicums, parthenocarpic Cucumber are grown in greenhouses round the year in the plains or subtropics area as off season vegetable production.

In European countries Tomato yield 63 - 145 tones/ha, the highest yield being in Denmark. In trials conducted under subtropical climate in India, where winter temperature does not favour fruit set in Tomato polyhouse yields have been found even better. With the findings of various research, hybrids are grown in low cost polyhouse, a yield of 88 157 tones per hectares has been obtained. At IARI New Delhi, an average yield of 100 tones per hectares has been reported from hybrid Naveen grown in medium cost greenhouse. Hence, overall $60-70$ percent more yield may be obtained from greenhouse cultivation.

Capsicum is a crop of temperate and subtropical climate in the subtopics in certain area, the low temperature does not allow proper plant growth and fruit set during winters; hence it is grown only during spring summer. A yield of 105.9 tones/ha could be obtained from mid September transplanted crop of California wonder in a low cost polyhouse. In medium cost polyhouse the yield are still better 149.4 tonnes/ha. 
Table 1 -Effect of Environment on Seedlings production of Vegetable crops under various conditions:-

\begin{tabular}{|c|c|c|c|c|c|c|c|c|c|c|c|c|}
\hline \multirow[t]{2}{*}{$\begin{array}{l}\text { S. } \\
\text { No. }\end{array}$} & \multirow[t]{2}{*}{$\begin{array}{l}\text { Types of } \\
\text { Structure }\end{array}$} & \multirow[t]{2}{*}{ Vegetables name } & \multicolumn{2}{|c|}{ No. of days of germination } & \multicolumn{2}{|c|}{$\begin{array}{l}\text { No. of days seedlings taken } \\
\text { for transplanting }\end{array}$} & \multicolumn{2}{|c|}{$\begin{array}{l}\text { Average seedlings } \\
\text { population/ form } 10 \mathrm{gm} \text { seed }\end{array}$} & \multicolumn{2}{|c|}{$\begin{array}{l}\text { Percentage of healthy } \\
\text { seedlings (Insect pest \& } \\
\text { disease free }\end{array}$} & \multirow[t]{2}{*}{$\begin{array}{l}\text { Average No. } \\
\text { of seeds } / 10 \\
\mathrm{gm}\end{array}$} & \multirow[t]{2}{*}{$\begin{array}{c}\text { Standard } \\
\text { minimum } \\
\text { germination \% } \\
\text { federal } \\
\end{array}$} \\
\hline & & & ${ }^{*} \mathrm{R}$ & ${ }^{* *} \mathrm{~W}$ & $\mathrm{R}$ & W & $\mathrm{R}$ & W & $\mathrm{R}$ & W & & \\
\hline \multirow[t]{6}{*}{1} & \multirow{6}{*}{$\begin{array}{l}\text { Open Field } \\
\text { (Control) }\end{array}$} & Tomato & 6.6 & 7.33 & 30.4 & 33.4 & 1500 & 1640 & 48.38 & 52.9 & 3100 & 75 \\
\hline & & Brinjal & 8.9 & 9.75 & 35.6 & 37.43 & 1080 & 1335 & 48 & 59.33 & 2250 & 60 \\
\hline & & Chilli & 11.65 & 13.45 & 35.63 & 38.16 & 882.75 & 987.3 & 58.85 & 65.82 & 1500 & 55 \\
\hline & & Cauliflower & 5.71 & 6.85 & 28.25 & 30.43 & 1680 & 1755 & 56 & 58.5 & 3000 & 75 \\
\hline & & Cabbage & 5.1 & 5.89 & 28.15 & 29.67 & 1525 & 1730 & 61 & 69.2 & 2500 & 75 \\
\hline & & Capsicum & 10.34 & 13.05 & 34.35 & 36.37 & 843.5 & 962.5 & 48.2 & 55 & 1750 & 55 \\
\hline \multirow[t]{6}{*}{2} & \multirow{6}{*}{$\begin{array}{l}\text { Insect Proof Net } \\
\text { House }\end{array}$} & Tomato & 8.1 & 7.1 & 34.7 & 33 & 1450 & 2270 & 46.77 & 73.22 & 3100 & 75 \\
\hline & & Brinjal & 7.85 & 8.67 & 34.7 & 36.08 & 1175 & 1305 & 52.22 & 58 & 2250 & 60 \\
\hline & & Chilli & 10.45 & 11.3 & 37.18 & 36.7 & 1170 & 1150 & 78 & 76.66 & 1500 & 55 \\
\hline & & Cauliflower & 6.1 & 6.61 & 31.2 & 32.32 & 1550 & 2080 & 51.66 & 69.33 & 3000 & 75 \\
\hline & & Cabbage & 4.5 & 4.2 & 30.8 & 31.1 & 1600 & 1782 & 64 & 71.28 & 2500 & 75 \\
\hline & & Capsicum & 11 & 12.55 & 33.47 & 35.62 & 955 & 1005 & 54.57 & 57.42 & 1750 & 55 \\
\hline \multirow[t]{6}{*}{3} & \multirow[t]{6}{*}{ Polyhouse } & Tomato & 6.53 & 7 & 25.25 & 24.3 & 2230 & 2460 & 71.19 & 79.35 & 3100 & 75 \\
\hline & & Brinjal & 6.98 & 6.7 & 28.35 & 31.7 & 1670 & 1701 & 74.22 & 75.6 & 2250 & 60 \\
\hline & & Chilli & 6.8 & 7.2 & 33.71 & 35.2 & 1105 & 1150 & 73.66 & 76.66 & 1500 & 55 \\
\hline & & Cauliflower & 5.34 & 5.5 & 23.25 & 24.5 & 2290 & 2575 & 76.33 & 85.83 & 3000 & 75 \\
\hline & & Cabbage & 4.65 & 4.5 & 22.7 & 23.34 & 1855 & 1935 & 74.2 & 78.12 & 2500 & 75 \\
\hline & & Capsicum & 8.2 & 9.3 & 30.2 & 32.75 & 1030 & 1090 & 58.85 & 62.25 & 1750 & 55 \\
\hline & & & & & & & & & & & & \\
\hline & & & ${ }^{*} \mathrm{R}=$ Rainy season & ${ }^{* *} \mathrm{~W}=$ & $V=$ Winter season & & & & & & & \\
\hline
\end{tabular}

Table 2-Average yield and it's component characters of parthenocarpic cucumber in natural ventilated polyhouse

\begin{tabular}{|l|l|l|l|l|l|l|l|l|r|}
\hline Hybrid & $\begin{array}{l}\text { Days to first } \\
\text { flowering }\end{array}$ & $\begin{array}{l}\text { Average No. } \\
\text { of days to } \\
50 \% \text { flowering }\end{array}$ & $\begin{array}{l}\text { Average No. } \\
\text { of days to } \\
\text { first picking }\end{array}$ & $\begin{array}{l}\text { Average } \\
\text { harvest } \\
\text { duration }\end{array}$ & $\begin{array}{l}\text { Average No. } \\
\text { of fruit per } \\
\text { plant }\end{array}$ & $\begin{array}{l}\text { Average } \\
\text { weight per } \\
\text { fruit (gm) }\end{array}$ & $\begin{array}{l}\text { Average } \\
\text { length per } \\
\text { fruit (cm) }\end{array}$ & $\begin{array}{l}\text { Average } \\
\text { breadth per } \\
\text { fruit (cm) }\end{array}$ & $\begin{array}{l}\text { Fruit yield per } \\
\text { plant (kg) }\end{array}$ \\
\hline Kian & 15.36 & 29.64 & 39.21 & 49.35 & 16.36 & 148.6 & 13.56 & 5.35 & 2.47 \\
\hline Isetis & 13.53 & 25.4 & 34.67 & 51.05 & 18.49 & 160.35 & 15.31 & 5.75 & 3.05 \\
\hline Hilton & 16.16 & 28.95 & 41.45 & 44.7 & 14.97 & 150.1 & 12.45 & 3.95 & 2.17 \\
\hline
\end{tabular}

Cucumber is cross-pollinated crops, hence it is less success of hybrid in green house and need to be hand pollination, beside parthenocarpic cucumber (development of fruit without fertilization) i.e. Sering, Hassan (in summer) Muhasan, Deenar (in winter) Keyon, Statis, Hilton, KUK-9 etc.

Parthenocarpic varieties can be grown in insect proof net house, natural ventilated green house conditions and having more yield round the year. Three crops of parthenocarpic cucumber can be grown over a duration of 1011 month with productivity range between 120-130 tones/ha with very high quality of fruits.
Cauliflower due to heavy rains during rainy season the soil is saturated in certain area and it becomes difficult to raise successful crop of early varieties' of cauliflower. The yield of cauliflower, Pusa Deepali, Pusa Katki, Early Chinese, Prince, Heavy silver plate and selected Early Dawn transplanted on 24 August in a plastic greenhouse cum rain shelter is 12.7 - 16.6 tones/ha. Similarly, Cauliflower Pant Gobhi 4 gives good yield in a low cost polyhouse. In subtropivcal region mostly tomato and capsicum has grown by farmers in green houses, But parthenocarpics cucumber is very remunerative crops. The KVK Sagar (represent the whole Bundelkhand) various trials was conducted in different specific places in district during 
2014 to 2016 at various location. The average result was mentioned in Table 2.

\section{Aftercare}

The nutritional requirement of crops grown in a polyhouse is similar to those of open field grown crops. In polyhouse, organic manure should invariably be used. Weed management is easier because the controlled irrigation, higher plant density and intensive cropping do not allow many weeds to grow. The vining crop or those having indeterminate growth habit need proper training and pruning. Such plants should be tied with strong, thin, nylon string and supported with the structural frame material. It has been observed that maintaining individual plants with only limited number of shoots/branches but accommodating higher plant population/ unit area gives higher yield with superior quality Tomato, Cucumber etc. Efforts should be made utilize as much aerial space as possible.

Diseases and insects also pose problem in polyhouse which should be controlled timely by using appropriate pesticides. It is better to cover the ground surface with plastic sheet for about a month during summer months to solarize the soil after 2-3 years gap. During winters, mulching of the soil surface with polythene sheet may help in raising the soil temperature to favour the fruit set, cheking he weeds and conserving the soil moisture. Foliar application of para chloro pheneoxy acid (20ppm) is very effective in increasing the fruit set and yield in Tomato

\section{References}

Bhardwas et.al (2012) Vegetable production under changing climate scenario $\left(1^{\text {st }}\right.$ September $-21^{\text {st }}$ September). Centre of advanced faculty training in horticulture (vegetables). Dept of Veg. Sci, Dr. Y.S.P.U. of Horti and Forestry, nauni, Solan (HP).
Chadha, K.L. (2006): Hand book of horticulture. Published by ICAR, New Delhi, India

Chandra, P. Sirohi P.S. Behra T.K. and Singh A.K. (2000) Cultivation of vegetable in polyhouse, Indian Horticulture. 45 : $17-25$.

Guo, S. Zheng Y., Joung, J.G., Liu S., Zhang, Z., Crasta, O. R., Sobral, B. W., X., Y., Huang S. and Fei, Z., 2010. Transcriptome sequencing and comparative analysis of cucumber flowers with different sex types. $B M C$ Genomics, $11: 384$.

Mangal, J.L. and Singh G.R. (1993) off season vegetable production In $A d v$ in hort. Vol 6. Vegetable crops : Part 2 PP. $673-685$

Rawat M, Maurya SK, Singh PK and Maurya RJ. 2014. Screening of improved cultivars of cucumber in naturally ventilated polyhouse under tarai condition of Uttrakhand. Journal of Hill Agriculture 5(1): 72-75

Singh, B. Dwivedi, S.K. and Sharma, J.P. (2000) Greenhouse technology for winter vegetables cultivation in cold arid zones. In : Dynamics of cold arid agriculture (Eds J.P. Sharma and A.A. Mir) Kalyani publishers, Ludhiyana, PP $279-293$.

Singh DK, Singh A, Punetha S and Singh B. 2012. Performance of some cucumber (Cucumis sativus L.) genotypes under protected condition in Uttrakhand-mid hills. National seminar on protected cultivation of vegetables and flowersA value chain approach. G.B. Pant University of Agriculture and Technology, Pantnagar, Uttrakhand, India. p 62

Sonwane, Y.R. Khandekar, S. Mishra, B.K. and Soundra pansian, K.K. (2008) Environment monitoring and control \& a polyhouse farm through Internet 
World Bank. India Country Overview, 2008 ,PP 1-6

Umekwe PN, Okpani FM, Okocha IO. 2015. Effects of different rates of NPK 15:15:15 and pruning methods on the growth and yield of cucumber (Cucumis sativus L.) in unwanaafikpo. International Journal of Science and Research 4(10): 36-39

Victory Seed Company. 1991. Germination standard for vegetable seed in interstate commerce.An Educational Resource of the Victory Seed Company [59 FR 64491,Dec. 14,1991]

Wani, K.P. Pradeep Kumar Singh, Asima Amin, Faheema mustaq and Zahoor Ahmad Dar (2011) Protected cultivation of tomato, capsicum and cucumber under Kashmir valley conditions, Asian Journal of science and technology, 1 (4) $056-061$

\section{How to cite this article:}

Yadav, K.S. 2018. High-tech Horticulture: Protected Vegetables Production in Subtropics under Changing Climatic Scenario. Int.J.Curr.Microbiol.App.Sci. 7(08): 1115-1122. doi: https://doi.org/10.20546/ijcmas.2018.708.126 